<綜 説 $>$

\title{
粘着剂用ウレタン樹脂の開発と応用 \\ Development and Application of Polyurethane for Pressure Sensitive Adhesive
}

\author{
大槻 司 $^{*}$. 重森 一範 ${ }^{*}$ \\ Tsukasa OTSUKI and Kazunori SHIGEMORI
}

\section{1.はじめに}

ウレタン樹脂を主剤として粘着剤を作る試みが全くな かったわけではないが, 実用的な粘着性の発現はウレタ ン樹脂では非常に難しいとされていた。現在, 特殊な用 途に少量使われているが, 汎用用途としては殆ど普及し ていない。ウレタン樹脂よりなる粘着剤に関する報告や 特許も，医療用のような極めて限られた分野で散見でき る程度である。これも粘着剤というより粘着性ゲル状弾 性体であり，テープやラベルに加工できるようなもので はない。

しかし, 粘着凧の用途が拡大し, 要求性能が多様化す ると, 従来使用されていたアクリル樹脂, ゴム, シリコ ン樹脂で設計された粘着剤では対応できない用途も多く なった。例えば, 工業用では再剥離性, 微粘着性を要求 する用途が急増しており, 市場のニーズに応えるために は，今までとは異なる樹脂で設計した新しい機能を有す る粘着剤が求められるようになった。医療用でも，皮㲊 刺激性や臭気が少ないばかりでなく，角質剥㒕量を少な くして貼り直しも可能にするような織細な性能が要求さ れるようになった。更に, 新しいニーズとして, 生分解 性を有する粘着剤も求められるようになった。ウレタン 樹脂による粘着剤は,このような市場動向より生まれた ものであり, 少量ではあるが徐々に普及し始めている。 ウレタン樹脂は典型的な縮合系のポリマーであり, アク リル樹脂に代表される重合系ポリマーでは得られない精

\footnotetext{
*東洋インキ製造(枯ポリマー研究所

兵庫県神戸市西区高塚台 1-5-7 于 651-2271

Toyo Ink Mfg. Co., Ltd.

Polymer Research Laboratory

1-5-7, Takatsukadai, Nishi-ku, Kobe-si,

Hyogo-ken, 651-2271 Japan
}

密な樹脂設計が可能である。用途に応じて主剤となるポ リマーをテーラーメードに合成できる技術力が問われて いる。

\section{2. 粘着剤用ウレタン樹脂の設計}

粘着剤は, エラストマー, 粘着付与剤, 及び様々な添 加㶡等より構成されているが，この中でもエラストマー は粘着性能を決める重要な材料である。実際に, 粘着剤 で適用されているエラストマーは，アクリル樹脂やSBS・ SIS 等のゴム系材料に限定されており, 素材選択の幅が それほど広いわけではない。

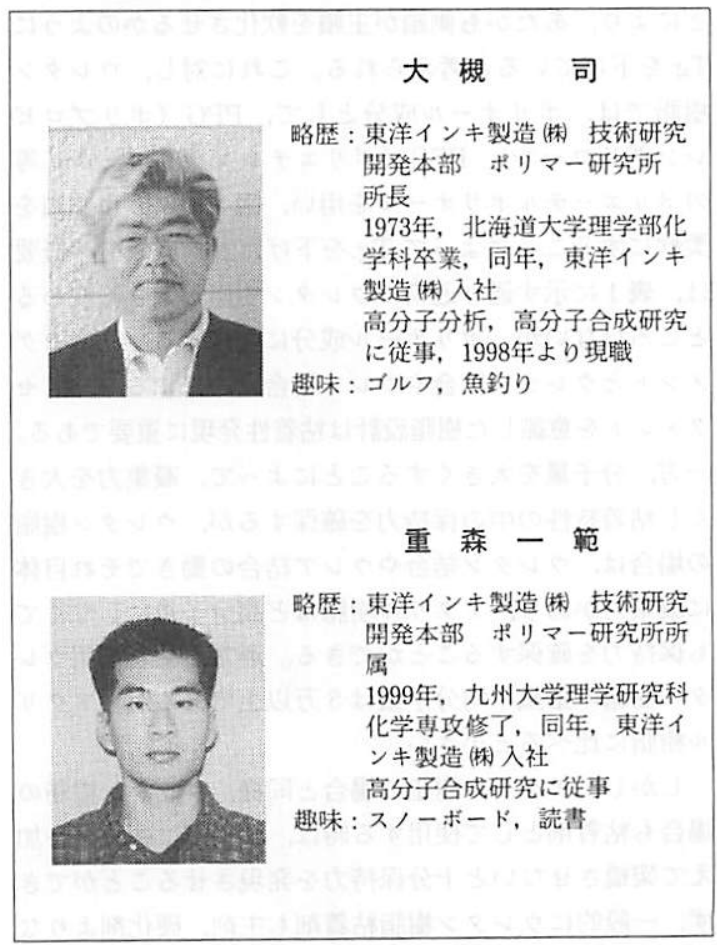


アクリル樹脂の場合, 単独で粘着剂の主剤になり得る が，どのようなアクリル樹脂でも粘着剤になるわけでは なく, ガラス転移点温度 ( $\mathrm{Tg}$ ) の低いモノマー組成を 選択し、分子量をできる限り大きくすることが粘着性 発現には必要である。アクリル樹脂では $\mathrm{Tg}$ が $-30^{\circ} \mathrm{C}$ 以 下, 重量平均分子量は 20 万以上の樹脂が使用されてい る。 $\mathrm{Tg}$ が $-30^{\circ} \mathrm{C}$ よ大きくなると, 粘着特性の中で粘 着力（ピール）や初期粘着力（タック）が不足する傾向 になり, 重量平均分子量が 20 万以下では保持力（クリー プ）を維持することは難しい。通常, 分子量が大きく なれば Tg や粘度は大きくなるため, 高分子量を保ちな がら樹脂の $\mathrm{Tg}$ を下げることは容易ではない。単独で 粘着性を発現する樹脂が，アクリル樹脂の中でも極めて 特殊な構造に限定されるのは以上のような理由からで ある。

ウレタン樹脂の場合も, アクリル樹脂同様, $\mathrm{Tg}$ がで きる限り低くなるよう樹脂構造を設計し, 重量平均分子 量を大きくすることが求められるが, 粘着特性を実用レ ベルまで到達させるには, 樹脂設計 ${ }^{1 \sim 8)}$ に多くの工夫を 要する。

アクリル樹脂では, 2-エチルヘキシルアクリレート のような長鎖アルキルアクリレートを共重合し，側鎖に 長鎖アルキル基をつけて Tg を下げている。アクリル樹 脂は, 図 1 のように主鎖が剛直な構造を有しているが, 側鎖として長鎖アルキル基のような柔軟な構造を持つこ とにより，あたかも側鎖が主鎖を軟化させるかのように $\mathrm{Tg}$ を下げていると考えられる。これに対し, ウレタン 樹脂では，ポリオール成分として，PPG（ポリプロピ レングリコール), PEG (ポリエチレングリコール) 等 のポリエーテルポリオールを用い, 図1のように主鎖を 柔軟にすることによって Tg を下げた。構成成分の概要 は, 表 1 に示す通り通常のウレタン樹脂と大きく変わる ところはないが，ポリオール成分に由来するソフトセグ メントとウレタン結合やウレア結合に由来するハードセ グメントを意識した樹脂設計は粘着性発現に重要である。 一方，分子量を大きくすることによって，凝集力を大き くし粘着特性の中の保持力を確保するが, ウレタン樹脂 の場合は, ウレタン結合やウレア結合の働きでそれ自体 に凝集力があり，アクリル樹脂ほど高分子量にしなくて あ保持力を確保することができる。通常，粘着剂用ウレ タン樹脂の重量平均分子量は 5 万以上であるが, アクリ ル樹脂に比べると小さい。

しかし，アクリル樹脂の場合と同様，ウレタン樹脂の 場合む粘着剤として使用する時は，塗工前に硬化剂を加 えて架橋させないと十分保持力を発現させることができ ず，一般的にウレタン樹脂粘着剤む主剤，硬化剤よりな

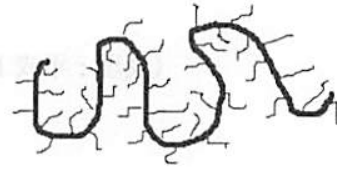

アクリル樹脂

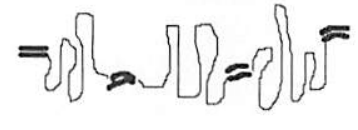

ウレタン楖脂

図 1 粘曾剂用樹脂の構造概念図

表 1 ウレタン樹脂粘着剤の構成成分

\begin{tabular}{l|l}
\hline $\begin{array}{l}\text { イソシアネート } \\
\text { ポリオール }\end{array}$ & TDI, MDI, HDI, IPDI \\
& ポリエステルポリオール, ポリエーテルポ \\
& リオール \\
銷延長剤 & アミン化合物, 多価アルコール \\
硬化剂 & イソシアネートアダクト体, アジリジン化 \\
& 合物, エポキシ化合物 \\
\hline
\end{tabular}

る二液硬化型である。

\section{3. 粘着剂用ウレタン樹脂とアクリル樹脂 の粘弾性}

ウレタン樹脂粘着風（東洋インキ製造 (捔製 サイア パイン SP201）と従来のアクリル樹脂粘着剂（東洋イ ンキ製造 (林)製 オリパイン BPS-5448）の動的粘弾性 を図 2 に示した。何れむ粘着剂用樹脂に所定の硬化剂を 加えて架橋させたもので，粘着剤塗工時と同じ処理をし たものである。

ウレタン樹脂粘着剂は約 $-50^{\circ} \mathrm{C}$ より弾性率が低下しは じめ, $-50 \sim 30^{\circ} \mathrm{C}$ 付近で急激に低下する。しかし, -30 ${ }^{\circ} \mathrm{C}$ 以上の弾性率変化は非常に緩やかで $120{ }^{\circ} \mathrm{C}$ 付近でも高 い弾性率を維持している。 $\tan \delta$ は, $-40 \sim 30^{\circ} \mathrm{C}$ に大き なピークがあるが, $10 〜 30^{\circ} \mathrm{C}$ 付近にも微かにピークがあ り，アクリル樹脂粘着刱とは明らかに異なる特異な粘弹 性を示している。一方, アクリル樹脂粘着剂は, $-10^{\circ} \mathrm{C}$ より弾性率が下がり始め, $0 \sim 20^{\circ} \mathrm{C}$ の常温付近では急激

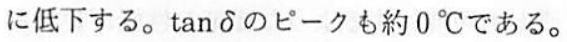

アクリル樹脂粘着剤は, $0{ }^{\circ} \mathrm{C}$ 以下では粘着力は大きく なるが剥離が滑らかではなくなる。常温付近では温度の 違いによって粘着特性は大きく变化する。このような粘 着剂の挙動は, 図 2 の動的粘弾性のデー夕とよく対応し ておりこれを裹付ける結果となった。

ウレタン樹脂粘着剤は, $-10^{\circ} \mathrm{C}$ 付近であ剥離は円滑で, 常温領域の温度の違いによる粘着特性の変化むアクリル 樹脂系ほど大きくはない。更に, $10 \sim 30^{\circ} \mathrm{C}$ の $\tan \delta$ のピー クは, ウレタン樹脂がこの温度領域に相変化を起こす成 分を含むことを示唆しており，常温付近で粘着特性が安 定している要因の一つと考えられる。 


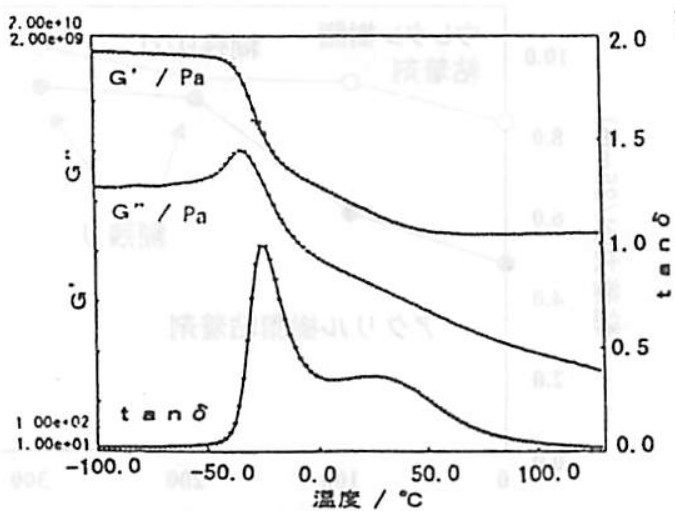

ウレタン樹脂粘着郕(サイアパイSP-201)

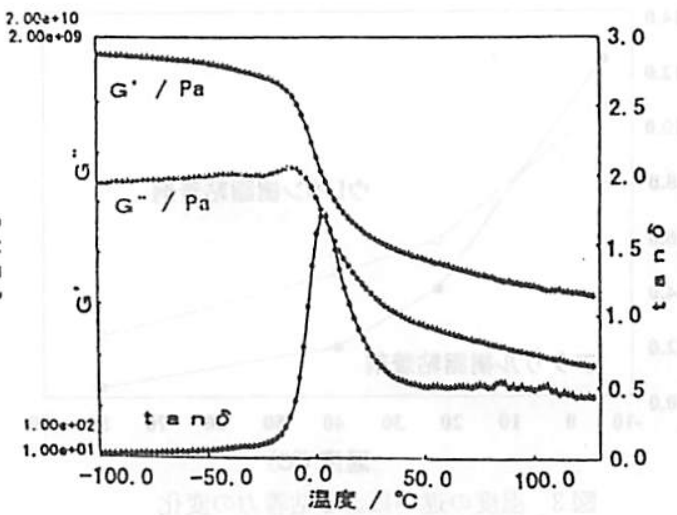

アクリル樹脂粘着剂(BPS-5448)

図 2 ウレタン樹脂粘着剂とアクリル樹脂粘着剤の動的粘弾性

\section{4. ウレタン樹脂粘着剤の特性と性能}

ウレタン樹脂粘着剤の特徵を，他の樹脂系の粘着剤と 比較して表 2 に示した。価格がアクリル樹脂系に比へてて 高いため, 汎用用途には適していないが，アクリル樹脂 系には見られない特徵が多くあり，これを生かした用途 展開を図ることができる。ウレタン樹脂粘着剤の特徵は, 主剂ポリマーであるウレタン樹脂自体の性質に由来する あのであり，アクリル樹脂系やゴム系で得ることが難し かった性能が容易に得られたり，逆に，他の樹脂系では 容易に得られる性能がウレタン樹脂粘着剤では難しかっ たり, 明らかに異なる挙動が隹められる。

\section{1 再剥離型粘着剤としての利用}

図 3 は温度の違いによる粘着力の変化を示したが, ウ レタン樹脂粘着剤はアクリル樹脂粘着剂に比べて, 常温
領域の温度の違いによる粘着力変化が小さく, 図 2 の動 的粘弾性の結果と良く一致していた。図 4 は塗工物を温 度 $40^{\circ} \mathrm{C}$, 湿度 $80 \%$ で保存したときの粘着力の变化をみ たものであるが, ウレタン樹脂粘着昘, アクリル樹脂粘 着剤とも, 安定した粘着力を示し, 時間が経過しても粘 着力は殆ど変化せず再剥離型粘着剤の特幑を示していた。 しかし, 図 5 のように, 耐候性試験のような苛酷な条件 に晒すと, アクリル樹脂粘着剂は, 時間の経過とともに 粘着力が大きくなり糊残りも認められる。ウレタン樹脂 粘着剤は，通常，アクリル樹脂粘着剤に比べて耐候性が 悪いといわれているが, 開発したウレタン樹脂粘着風で は粘着力の変化は小さく，もともと粘着力が大きいにす かかわらず糊残りは全く起こらない。このような性能よ りこのウレタン樹脂粘着剤は優れた再剥離性を示すこ とが期待できる。

表 2 ウレタン樹脂粘着剤の一般的な特徵と他の樹脂系との比較

\begin{tabular}{|c|c|c|c|}
\hline \multirow{2}{*}{ 粘着剂 } & \multirow{2}{*}{ 樹 脂 } & \multicolumn{2}{|l|}{ 特 } \\
\hline & & 所 & 短 \\
\hline ウレタン系 & $\begin{array}{l}\text { ウレタン } \\
\text { ウレタンゥレア }\end{array}$ & 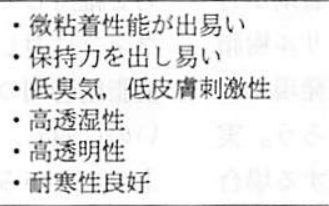 & $\begin{array}{l}\text { ・強粘着力を出し難い } \\
\text { ・タックさい } \\
\text { ・ ポリオレフィンへの接着強度小さい } \\
\text { ・価格高い }\end{array}$ \\
\hline アクリル系 & $\begin{array}{l}\text { アクリル酸エステル } \\
\text { 共重合体 }\end{array}$ & $\begin{array}{l}\text { ·強粘着性が出易い } \\
\text { ·タック出し易い } \\
\text { ·酎候性に優れる } \\
\text { ·高透明性 }\end{array}$ & $\begin{array}{l}\text { - 耐寒性不良 } \\
\text { - 臭気, 刺激性あり }\end{array}$ \\
\hline ゴム系 & $\begin{array}{l}\text { 天然ゴム } \\
\text { SBS, SIS }\end{array}$ & $\begin{array}{l}\text { ・被着体の選択性小さい } \\
\text { ・価格が安い }\end{array}$ & $\begin{array}{l}\text { ·耐候性著しく不良 } \\
\text { ・透明性不良 }\end{array}$ \\
\hline シリコン系 & シリコンゴム & $\begin{array}{l}\text { - 適用温度範囲が広い } \\
\text { • 耐候性, 耐薬品性に倀れる }\end{array}$ & $\begin{array}{l}\text { ・粘着特性の調整が難しい } \\
\text { ・価格高い }\end{array}$ \\
\hline
\end{tabular}




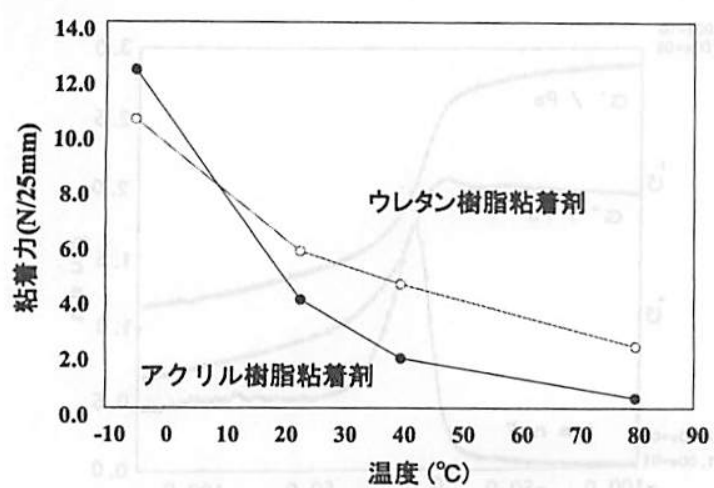

図 3 温度の透いによる粘着力の变化 被着体：SUS304

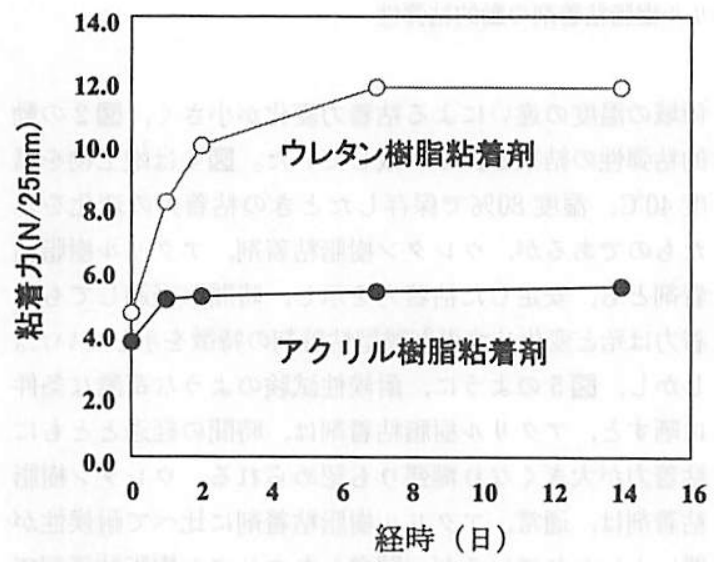

図 4 㳴工物保存中のの粘着力変化 被着体：SUS304

一般的に, ウレタン樹脂で粘着剤を設計すると, 強粘 着にすることは難しいが, 微粘着領域での粘着力の調整 は比較的容易である。アクリル樹脂粘着剤は, 強粘着か ら微粘着まで幅広く設計できるといわれているが, アク リル樹脂単独で微粘着性を出すことは, モノマー組成を 最適化しても容易ではなく, 再剥離型粘着剤として, 微 粘着型を主に考えるとすれば, ウレタン樹脂粘着剂が有 利である。また, ウレタン樹脂の凝集力はアクリル樹脂 に比べて大きいと言われているので, 再剥離性発現には 有利と考えられるが，これには検証が必要であろう。実 際の系では, 粘着剤の微量成分が被着体に移行する場合 が多く, 主風樹脂の凝集力だけで再剥離性を議論するこ とは難しいが, 被着体への移行成分は, 粘着剤にもとも と含まれていた低分子物や処理中に生じた樹脂分解物等 と考えられる。再剥離性発現のためには, 低分子物や分 解物の低減が不可欠であり, 可塑剂や低分子粘着付与剂 のブレンドは好ましくない。また, 熱分解を起こし易い アクリル樹脂よりもウレタン樹脂は, 分解物を出しにく

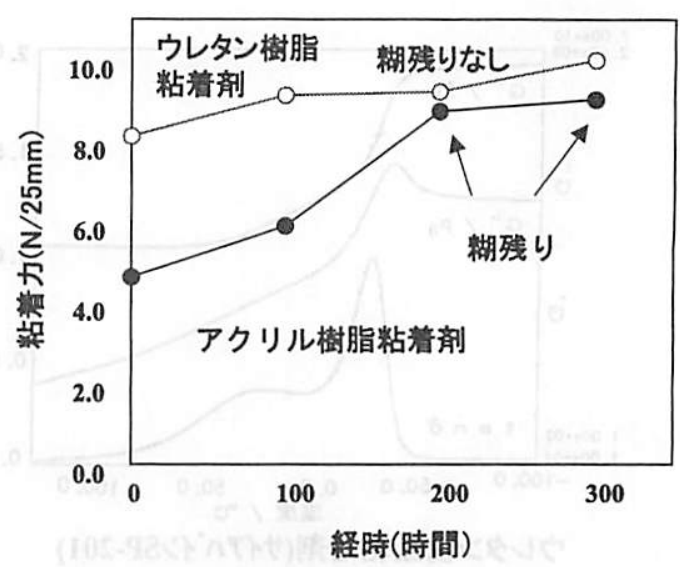

図 5 耐候性試験による粘着力変化 被着体：SUS304

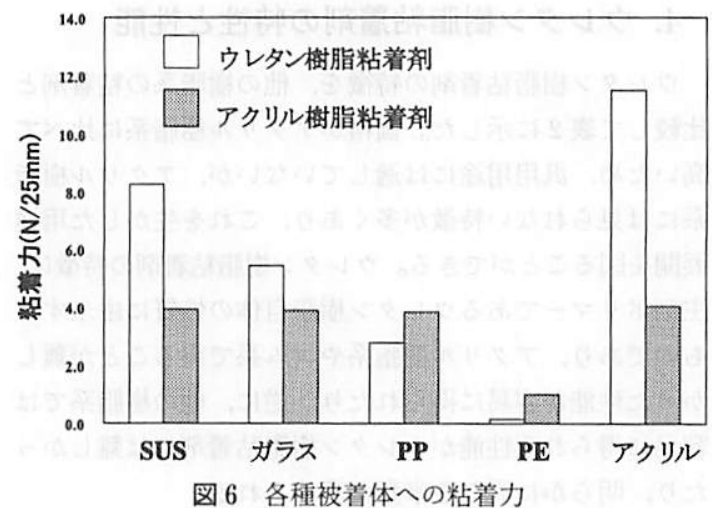

いので, 再剥離型粘着剤には適している。但し, ある種 のポリエーテルポリオールは熱分解し易く糊残りを起こ す場合があるので注意が必要である。

図 6 は各種被着体に対するウレタン樹脂粘着剤とアク リル樹脂粘着剤の粘着力を示したものである。アクリル 樹脂系がどのような素材に対しても, あるレベルの粘着 力を維持しているのに対し, ウレタン樹脂系はポリオレ フィンに対し全く接着しない。表 3 に代表的なウレタン 樹脂粘着風の粘着特性を示したが, 保持力が比較的大き いのに対し, 粘着力, タックは出にくい傾向がある。以 上のことから，アクリル樹脂粘着剤とウレタン樹脂粘着 刘は異なる様式で接着している可能性が高い。アクリル 樹脂粘着剤がいわゆるレオロジー的な接着であるのに対 し, ウレタン樹脂粘着剤の場合はレオロジー的な接着に 加えて, 被着体の極性基との相互作用が大きく関与して いるむのと推定される。

\section{2 医療用粘着凨としての利用}

ウレタン樹脂粘着剤を皮䖉に貼付するとアクリル樹脂 
表 3 ウレタン樹脂粘着㶡の粘着特性

\begin{tabular}{c|c|c|c}
\hline 粘着剤の種類 & 粘着力 $(\mathrm{N} / 25 \mathrm{~mm})$ & ボールタック $23^{\circ} \mathrm{C}, 65 \%$ & 保持力 $40^{\circ} \mathrm{C}, 1 \mathrm{~kg}$ \\
\hline サイアパイン SH-101 (微粘着型) & $0.5 \sim 7.0$ & $4 \sim 5$ & $\mathrm{NC}(72000 \mathrm{sec}$ 以上) \\
サイアバイン SP-201 (中粘着型) & $7.0 \sim 15.0$ & $7 \sim 11$ & $\mathrm{NC}(72000 \mathrm{sec}$ 以上) \\
サイアパイン試作品 (強粘着型) & $15.0 \sim 20.0$ & $4 \sim 5$ & $\mathrm{NC}(72000 \mathrm{sec}$ 以上) \\
\hline
\end{tabular}

サイアパイン：東洋インキ製造俶製ウレタン樹脂粘着剤

表 4 ウレタン樹脂粘着阂の透湿性

\begin{tabular}{c|c}
\hline 粘着剤の種類 & 透湿性 $\mathrm{g} / \mathrm{m}^{2} \cdot 24 \mathrm{~h}(\mathrm{JIS} 1099)$ \\
\hline サイアバインSH-101 (微粘着型) & $2000 \sim 2200$ \\
サイアバイン SP-201 (中粘着型) & $2100 \sim 2500$ \\
アクリル粘着剤BPS-5448 & $600 \sim 700$ \\
\hline
\end{tabular}

サイアパイン: 東洋インキ製造修製ウレタン樹脂粘着剂 膜厚 $30 \mu$

BPS-5448：東洋インキ製造(媩製アクリル樹脂粘着剤 膜厚 $30 \mu$

系やゴム系に比べて, 非常にしっとりした感触が実感で きる。ウレタン樹脂粘着剤はアクリル樹脂粘着剤に比ヘ て具気が少なく，皮虔刺激性も殆どない。アクリル樹脂 系やゴム系粘着剤を剥がした後のべタべタとした皮膚に 残る不快感は, ウレタン樹脂粘着剤ではあまり感じられ ない。ウレタン樹脂粘着剤は透湿性に優れており, 表 4 に示すようにアクリル樹脂粘着剤に比べて $3 \sim 4$ 倍の透 湿性を有することが確挡されている。また，アクリル樹 脂粘着剤ではモノマーの残留は避けられず，しかも，了 クリル酸のような刺激性の強いモノマーの使用が良好な 粘着特性確保には不可欠であるため, 臭気や皮虚刺激性 は避けられない。これに対し, ウレタン樹脂粘着剤は残 留モノマーも少なく, 生体に対し非常にやさしい粘着剤 といえる。

ウレタン樹脂粘着剤は, 皮虞刺激性が少ないだけでな く, 周波数特性も優れていることから, 生体電極材 ${ }^{9 \sim 15}$,

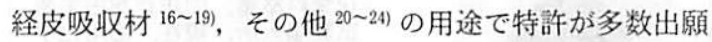
されている。

\section{3 生分解性粘着㓮としての利用}

ポリ乳酸による生分解性フィルムが開発され, 生分解 性粘着戍の需要も現実のものになりつつある。生分解性 粘着剤は, 概初天然樹脂系と合成樹脂系に大別されるが, 天然樹脂系としては天然ゴムやロジン等の天然素材より なる粘着剤 ${ }^{25}$, 合成樹脂系では脂肪族ポリエステルか

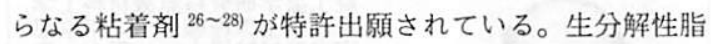
肪族ポリエステルをポリオール成分としたウレタン樹脂 は, イソシアネート成分の構造や存在比を最適化すると 生分解性にすることができる。このようなウレタン樹脂 を用いた生分解性粘着郕む特許出願 ${ }^{29}$ されている。

\section{5. 終わりに}

ウレタン樹脂粘着剤は構成成分や分子量を変えること により，幅広い性能を引き出すことができる。既に確認 されている再剥離性, 低臭気, 低皮虑刺激性, 高透湿性 の他にす, 優れた性能を発現するポテンシャルをウレ夕 ン樹脂粘着剤は有しており，いろいろな用途に展開する ことが考えられる。ウレタン樹脂は自在に樹脂設計をし て容易に合成できるのが強味であり, 様々なニーズにこ たえる粘着凨を作ることができるはずである。高次構造 あ考慮して，今までと異なる視点の設計をすれば，新し い機能が発現し研究が更に進展してゆくことが期待でき る。

\section{参 考 文 献}
1）特開 2000-256629 東洋インキ製造
2）特開 2000-256630 東洋インキ製造
3）特開 2000-256638 東洋インキ製造
4）特開 2000-256639 東洋インキ製造
5）特開 2000-256640 東洋インキ製造
6）特開 2000-328032 東洋インキ製造
7）特開 2000-328034 東洋インキ製造
8）特開 2000-328035 東洋インキ製造
9）特公平 6-18558 夕キロン
10）特開平 1-266161 タキロン
11）特開平 1-304109 夕キロン
12）特開平 2-131753 夕キロン
13）特開平 2-261882 夕キロン
14）特開平 3-178647 夕キロン
15）特開平 4-303433 タキロン
16）特開平 4-13618 タキロン
17) 特開平 4-13620 タキロン
18）特開平 4-18023 タキロン
19）特開平 9-188618 夕キロン
20）特開平 2-229876 タキロン
21）特開平 4-343811 夕キロン
22) 特開平 5-178741 タキロン
23）特開平 6-79847 夕キロン
24）特開平 6-80758 夕キロン
25）特開平 7-173442 東洋インキ製造
26）特開平 11-21533 昭和高分子
27）特開平 11-279393 三井化学
28）特開平 6-228508 日東電工
29）特開平 6-21340 昭和高分子 